\title{
Ny definisjon av epilepsi
}

\author{
Diagnosen epilepsi kan nå stilles etter kun ett uprovosert epileptisk anfall. Dette gir bedre muligheter \\ for å komme tidlig i gang med behandling hos særlig anfallsutsatte pasienter.
}

Epilepsi er et paraplybegrep som omfatter en rekke tilstander med forskjellige årsaker, ytringsform og prognose. Fellesnevneren er epileptiske anfall.

Innenfor fagfeltet epileptologi har det i mange år vært vanskelig å oppnå internasjonal enighet om helt grunnleggende temaer, som en klinisk definisjon av epilepsi. International League Against Epilepsy (ILAE) har kommet frem til en todelt definisjon. Den teoretiske, som definerer selve begrepet (konseptuell definisjon), ble vedtatt i 2005 (1). Den er nå supplert med en praktisk (operasjonell) definisjon til bruk i den kliniske hverdagen (2).

\section{Konseptuell definisjon}

Epilepsi er en hjernesykdom kjennetegnet ved en vedvarende predisposisjon til å generere epileptiske anfall. Et epileptisk anfall er et forbigående symptom eller tegn på en abnorm, eksessiv og synkron nevronal aktivitet $\mathrm{i}$ hjernen.

Begrepet epilepsi består av tre elementer: minst ett epileptisk anfall, vedvarende funksjonsforstyrrelse i hjernen som øker risikoen for nye anfall, og ledsagende nevrobiologiske, kognitive og psykososiale problemer.

Denne tredelingen er nyttig som bakgrunn for både utredning og behandling av mennesker med epilepsi: For det første må de kliniske symptomene være forenlig med et epileptisk anfall. For det andre må årsaken til funksjonsforstyrrelsen alltid utredes og eventuelt behandles. For det tredje er interiktale og/eller postiktale kognitive forstyrrelser vanlig. Psykososiale problemer er i varierende grad knyttet opp mot diagnosen og krever en helhetlig og ofte tverrfaglig tilnærming som ikke må neglisjeres.

\section{Operasjonell definisjon}

Epilepsi er en hjernesykdom definert ved ett av følgende kriterier: minst to uprovoserte epileptiske anfall med $>24$ timers mellomrom, eller ett uprovosert epileptisk anfall og en sannsynlighet for ytterligere anfall som er like stor som hos dem som har hatt to, dvs. $>60 \%$ sannsynlighet, innenfor de neste ti årene, eller at anfallene er ledd $i$ et epilepsisyndrom.

Frem til i dag har to uprovoserte anfall vært et krav for å kunne stille epilepsidiagnosen (3). Etter kun ett uprovosert anfall er det nemlig funnet at risikoen for nye anfall er $<50 \%$ (4). Mange klinikere har imidlertid erfart at noen av disse pasientene har en betydelig høyere risiko for nye anfall enn andre. International League Against Epilepsy har følgelig tatt konsekvensen av dette, slik at diagnosen nå kan stilles etter kun ett uprovosert anfall dersom klinikeren vurderer risikoen for nye anfall til å være betydelig, for eksempel ved en påvist epileptogen lesjon på MR og/eller sikker epileptiform aktivitet i EEG.

\section{Grundig vurdering før behandling}

Epilepsidiagnosen er ikke ensbetydende med oppstart av behandling. Før man iverksetter behandling må man, som ellers i medisinen, foreta en grundig risiko-nytte-vurdering sammen med pasient og eventuelt pårø-

\section{«Når et barn med en aldersrelatert epilepsi har passert den sårbare alderen og er blitt anfallsfri, anses det ikke lenger å ha epilepsì}

rende. Noen pasienter som fyller diagnosekriteriene, kan ha så få eller lette anfall at de er best tjent med å gå ubehandlet, eventuelt vente med behandling. En slik avgjørelse må med andre ord individualiseres.

Epileptiske anfall som oppstår i det tidlige forløpet ( $<1$ uke) av en hjerneskade (hjerneslag, hodetraume, m.m.), i forbindelse med en aktiv infeksjon i hjernen eller ved en metabolsk/toksisk forstyrrelse, for eksempel abstinensanfall, kalles akutte symptomatiske eller provoserte anfall (5). De representerer ikke epilepsi, men kan disponere for det. Akutte symptomatiske anfall er et ganske veldefinert begrep, i motsetning til den mer vage betegnelsen leilighetsanfall eller situasjonsrelaterte anfall, som mange setter i sammenheng med anfallsutløsende faktorer som søvnmangel og stress.

Uprovoserte anfall skal i prinsipp komme «ut av det blå», men kan også komme i forbindelse med belastninger og lite søvn. Disse anfallsutløsende faktorene skal imidlertid ikke overstige hva noen hver kan utsettes for i dagliglivet. International League Against Epilepsy definerer ikke anfall etter søvndeprivasjon som provoserte anfall (5). Det første anfallet ved generaliserte epilepsier, slik som juvenil myoklon epilepsi, opptrer ofte ved oppvåkning etter en natt med lite søvn (6). I en undersøkelse var ikke residivraten etter et førstegangs anfall lavere for anfall i forbindelse med søvnmangel enn etter spontane anfall (7).

\section{Symptom eller sykdom?}

Om epilepsi er et symptom eller en sykdom, har vært et kontroversielt tema i fagfeltet i mange år. De som hardnakket hevder at epilepsi er et symptom, viser til at den samme etiologien, for eksempel mutasjon i natriumkanalgenet $S C N 1 A$, kan gi opphav til forskjellige epilepsiformer, mens samme epilepsisyndrom, for eksempel West eller Lennox-Gastauts syndrom, kan ha forskjellige årsaker.

Vi har lenge hevdet at det er de epileptiske anfallene som er symptomet, mens epilepsi - med alle dens konsekvenser fortjener sykdomsbetegnelsen. International League Against Epilepsy støtter nå dette synet (2). Man viser blant annet til at mange andre tilstander med høyst forskjellige årsaker, for eksempel kreft, også blir betegnet som sykdommer.

Epilepsi er ikke nødvendigvis en livslang sykdom. Når et barn med en aldersrelatert epilepsi, for eksempel absensepilepsi eller godartet barneepilepsi, har passert den sårbare alderen og er blitt anfallsfri, anses det ikke lenger å ha epilepsi.

Også andre pasienter som har vært anfallsfrie de siste ti årene og ikke har brukt anfallsbeskyttende legemidler de siste fem årene, anses ikke lenger å ha diagnosen. Men International League Against Epilepsy har valgt å bruke uttrykket «resolved» fremfor «cured». Det innebærer at man ikke kan garantere for fremtidig anfallsfrihet (2).

\section{Kliniske konsekvenser}

For klinikeren innebærer den nye definisjonen at hos pasienter som har hatt ett uprovosert anfall, bør man vie risikoen for nye anfall større oppmerksomhet. Å starte behandling hos særlig anfallsutsatte pasienter kan forebygge ikke bare nye anfall, men også psykososiale følgeproblemer. Hvordan den nye definisjonen vil påvirke epidemiologisk og annen epilepsirelatert forskning, er usikkert. For pasienter som har hatt ett epileptisk anfall, er det av stor betydning å få vite om de har epilepsi eller ei.

Karl 0. Nakken

karln@ous-hf.no

Eylert Brodtkorb 
Karl O. Nakken (f. 1945) er spesialist i nevrologi med særlig kompetanse innen epilepsisykdommer. Han er medisinsk sjef ved Spesialsykehuset for epilepsi (SSE) ved Oslo universitetssykehus.

Forfatter har fylt ut ICMJE-skjemaet og oppgir ingen interessekonflikter.

Eylert Brodtkorb (f. 1948) er overlege ved Avdeling for nevrologi og klinisk nevrofysiologi ved St. Olavs hospital og professor i bistilling ved Institutt for nevromedisin, Norges teknisknaturvitenskapelige universitet. Han arbeider hovedsakelig med epilepsi.

Forfatter har fylt ut ICMJE-skjemaet og oppgir ingen interessekonflikter.

\section{Litteratur}

1. Fisher RS, van Emde Boas W, Blume W et al. Epileptic seizures and epilepsy: definitions proposed by the International League Against Epilepsy

(ILAE) and the International Bureau for Epilepsy (IBE). Epilepsia 2005; 46: 470-2.

2. Fisher RS, Acevedo C, Arzimanoglou A et al. ILAE official report: a practical clinical definition of epilepsy. Epilepsia 2014; 55: 475-82.

3. Hauser WA, Annegers JF, Kurland LT. Prevalence of epilepsy in Rochester, Minnesota: 1940-1980. Epilepsia 1991; 32: 429-45

4. Berg AT, Shinnar S. The risk of seizure recurrence following a first unprovoked seizure: a quantitative review. Neurology 1991; 41: 965-72.

5. Beghi E, Carpio A, Forsgren L et al. Recommendation for a definition of acute symptomatic seizure. Epilepsia 2010; 51: 671-5.

6. Lawn N, Lieblich S, Lee J et al. Are seizures in the setting of sleep deprivation provoked? Epilepsy Behav 2014; 33: 122-5

7. Genton P, Thomas P, Kasteleijn-Nolst Trenité DG et al. Clinical aspects of juvenile myoclonic epilepsy. Epilepsy Behav 2013; 28 (suppl 1): S8-14.

Mottatt 1.5.2015, første revisjon innsendt 11.5. 2015, godkjent 12.5. 2015. Redaktør: Hanne Støre valeur.

Publisert først på nett. 